\title{
Sojourner Culture Shock: Assessing the Role of Exposure in Intrapersonal Identity Conflict
}

\author{
Ahmed M. Asfahani ${ }^{1}$ \\ ${ }^{1}$ Collage of Business Administration, University of Business and Technology, Dahban, Saudi Arabia \\ Correspondence: Ahmed M. Asfahani, Collage of Business Administration, University of Business and \\ Technology, Dahban, Saudi Arabia. E-mail: ahmed.asfahani2@gmail.com
}

Received: May 26, 2017

doi:10.5539/ijps.v9n3p12

\author{
Accepted: June 10, 2017 \\ Online Published: June 14, 2017 \\ URL: http://doi.org/10.5539/ijps.v9n3p12
}

\begin{abstract}
This research assesses the relationship between intercultural exposure variables - the length of time spent in the United States, the length of previous experience outside Saudi Arabia, the length of time studying English as a second language, and the frequency and nature of interactions with Americans - and intrapersonal identity conflict. To assess this relationship, the researcher conducted a survey of Saudi Arabian students studying in the United States, which collected information on exposure variables, as well as employing Leong and Ward's (2000) Ethno-Cultural Identity Conflict Scale (EICS). A Pearson correlation test was conducted to examine the relationship between the Saudi sojourners' intercultural exposure and their identity conflict scores to conclude that there is not a relationship between exposure and identity conflict.
\end{abstract}

Keywords: intrapersonal identity conflict, Saudi Arabian students, study abroad, acculturation

\section{Introduction}

There are a number of factors that determine how one will respond to a foreign culture. According to Furnham and Bochner (1982), there are three conditions that influence the duration and the extent of culture shock: 1) cultural differences, 2) individual differences, and 3) sojourner' experiences. Guirdham (1999) states that an individual's ability to survive culture shock is affected by "knowledge of the culture and its language, stereotypes of and attitudes towards people in the other culture, being able to suspend evaluation of other people's behavior and understanding the self as a cultural being" (p. 272). Ward (1996) claims that cross-cultural adaptation for sojourners is affected by additional factors, including knowledge about the host culture, the length of residence, the amount of interaction with the people from the host culture, previous experiences in a foreign country, and whatever cultural orientation programs exist. Worchell and Mitchell (1972) state that the learning process is directly connected to cultural readjustment.

This research assesses the relationship between intercultural exposure variables - the length of time spent in the United States, the length of previous experience outside Saudi Arabia, the length of time studying English as a second language, and the frequency and nature of interactions with Americans - and intrapersonal identity conflict. The intercultural background variables are hypothesized to impact how one will respond to American culture and thus his or her levels of intrapersonal identity conflict. To assess this relationship, the researcher conducted a survey of Saudi Arabian students studying in the United States, which collected information on length of previous experience abroad and time studying English, and details on prior interactions with Americans, as well as employing Leong and Ward's (2000) Ethno-Cultural Identity Conflict Scale (EICS).

Socialization is a human process (Herrmann, 2007). This study focuses on the exposure factors that are related to socialization as measured by intrapersonal conflict. Understanding this relationship, or even the meaning in the lack of relationship, is both of practical and theoretical significance. Theoretically, this study contributes to the study of international students and acculturation to their host cultures. Practically, the results of this study stand to advance relationships between Saudi Arabians and Americans. Understanding the role of exposure to American culture's relationship to intercultural identity conflict is a step towards identifying the sources of such conflicts through analytical frameworks. Understanding how cultural beliefs and values can hinder cooperative or advance beneficial interaction and to what extent, if any, exposure to the culture is related to acceptance of the culture is particularly important for civilizational fault lines, such as between the United States and Saudi Arabia (Huntington, 1996). 
In 1996, Samuel P. Huntington postulated that future conflicts would revolve around civilizational cultural differences. This thesis was supported by the subsequent terrorist attacks of September 11, 2001. The events of this date changed the way that many Americans perceive Arabs and Muslims (Livengood \& Stodolska, 2004). Furthermore, Saudi Arabia and Afghanistan were held most culpable for the attacks, which has had calamitous repercussions for relationships between individuals from these countries and Americans. Repercussions include both diplomatic consequences and emotional contempt, including toward Middle Eastern students studying in the United States (Livengood \& Stodolska, 2004). This reaction not only impacts how Saudi Arabian students are viewed by Americans, but also how they perceive themselves, which ultimately impacts the ability of Saudi sojourners in the United States to successful learn and socialize within the host culture. Thus, this study is built on the premise that intrapersonal identity conflicts - those which arise from personal conflict resulting from cultural clashes and the need to find oneself from within the competing demands of cultures - are related to exposure to the competing culture (Erikson, 1950; Leong \& Ward, 2000). Within this study, American culture is viewed as the culture that is competing with Saudi Arabian culture for Saudi students studying abroad. Moreover, exposure is treated as a composite of the length of time spent in the United States, the length of previous experience outside Saudi Arabia, the length of time studying English as a second language, and the frequency and nature of interactions with Americans. These variables of exposure are considered to be part of the larger picture of acculturation.

This research employs a quantitative approach to measure participants' exposure to American culture and identity conflict. The study relies on Leong and Ward's EICS and a brief online questionnaire designed by the research to obtain data on exposure and conflict. The Statistical Package for the Social Sciences (SPSS) was used to analyze the data.

Although acculturation, identity conflict, and exposure have been researched in Western contexts, the Arabic and Muslim experience is absent within the literature. To date, there have not been any studies focusing on the intercultural exposure of Saudi sojourners or that relate exposure to identity conflict. There is a call in the literature (c.f., Leong \& Ward, 2000; Ward, Stuart, \& Kus, 2011) to use direct measures, such as the EICS, to examine the intrapersonal identity conflict among the Saudi student sojourners in the United States.

\section{Literature Review}

Identity conflict is of interests as it can hinder positive interactions among individuals, particularly those of different cultures (Slocum-Bradley, 2008). Individuals of differing cultures often experience challenges in engaging with others for fear of compromising their own culture and beliefs or for the possibility of offending another's culture. Thus, the fear of loss of personal identity can be anxiety-inducing, especially for minorities (Slocum-Bradley, 2008). Identity conflict arises when this fear becomes a mental struggle, causing hyper-awareness of one's own culture, such as language, food, religion, clothing, entertainment, and education. A psychological binary is developed in which either the individual's native or host culture is perceived as negative and the other as positive (Salhi, 2006).

Saudi and American cultures yield an ideal case for assessing identity conflict as the cultures are considerably different. Language, for instance, marks Saudis within the United States as the "other" (Said, 1977). The terrorist attacks of February 26, 1993 and September 11, 2001 have resulted in Arabic and Muslim appearing individuals to be perceived as terrorists (Livengood \& Stodolska, 2004). Haas (2012) argues that Saudi sojourners may be viewed as an affront to Americans and, in particular, those speaking in Arabic may be perceived to view their own culture as superior to American culture.

These potential conflicts of acculturation are perceived to be able to be alleviated by cultural acclimation programs, such as orientations for Saudi students in the United States. Saudi sojourners come through the King Abdullah Scholarship Program (KASP). Originating in 2006, KASP has placed thousands of Saudi students abroad. Most of these students, however, have limited or no interaction with individuals of other cultures prior to their participation. This may further exacerbate cultural clashes as the students enter the full emersion of studying abroad (Law \& Guo, 2010). This acculturation stress can then lead to identity conflict (Ward \& Kennedy, 1999). It is therefore important, as is the emphasis of this study, to understand the factors associated with identity acculturation in order to ameliorate the dissonance caused by identity conflict.

While socialization is part of human nature (Habernas, 2003; Erikson, 1950), individuals often identify and socialize by race, social classes, familial lineages, and other anthropological constructs. Cultures often used these assessments to divide people into in-groups and out-groups (Brewer, 1999). Sojourners often exist as constituents of out-groups, relaying a sense of rejection or cultural tension. It is hypothesized within this research that exposure to American culture increased acceptance of and within the culture and decreases identity conflict. 
Acceptance as result of shared membership occurs within a social structure (Tajefel \& Turner, 1996). Status inequality, as explained by social identity theory, is the manifestation of in-group bias (Smith, 1991). Greene (1999) extends this concept to sojourner acceptance within host cultures.

As predicted by social identity theory, sojourners traditionally identify with individuals of their native culture more readily than they do with individuals of their host culture. It is human nature to gravitate towards like individuals. This also entails that in the United States, Saudi sojourners are more likely to interact with other Saudis than with Americans. As part of the Saudi sojourner in-group, individuals place emotional value and significance on the culture of this group as an antecedent of social identity (Rubin \& Hewstone, 2004).

Acculturation theory can be applied to Saudi sojourner interaction with their American host culture (c.f., O'Guinn \& Faber, 1985). Acculturation is the process by which immigrant gradually understand and adapt to their host culture. Lin and Yi (1997) find that Asian sojourners struggle with balancing acculturation and maintaining their host culture. Stereotypes are common obstacles to acculturation (Perna, 2009). Therefore, as previously discussed, the post-September 11, 2011 terrorist attacks stereotypes of Arabs and Muslims may prompt Saudi sojourners to be hyperaware of acculturation and acceptance. In Persons' (1987) three-stage model of acculturation - contact, acculturation, assimilation - individual of different cultures interact with each other to form accommodation needed to avoid intergroup conflict. Thus, Saudi sojourners must be exposed to American culture to prompt the adaptation to American language and social rituals. This is, in turn, theorized to limit the conflict between Saudi and American culture, reducing instances of xenophobia and aggression against Saudi sojourners.

\section{Methods}

The research question assessed within this study is: "Is there a relationship between the intercultural background variables (the length of time spent in the United States, the length of previous experiences outside Saudi Arabia, the length of time studying English as second language, and the frequency and nature of interactions with Americans) and intrapersonal identity conflict?" A Pearson Product Moment Coefficient of Correlation test was conducted to examine the relationship between the Saudi sojourners' intercultural backgrounds and their identity conflict scores.

The research uses a cross-sectional survey design to collect data on the target population, Saudis studying in the United States, at a single point in time. This design is appropriate for generalizing the results from a sample to the broader population of interest (c.f., Lankshear \& Knobel, 2004). Thus, the researcher seeks to form conclusions regarding the relationship between exposure variables and identity conflict in Saudi sojourners and generalize these findings to international sojourners. Data were collected through a survey of Saudi Arabian students studying in the United States. This study was limited to the Saudi students in the United States of America who are involved in the King Abdullah's Scholarship Program and over 18 years old. This inclusion criterion provides a sampling frame of forty-five thousand individuals (Maati, 2011). All eligible individuals received the call for participants through the Saudis in the United States database. Potential participants received the IRB approved invitation explaining the study's purpose, the role of participants, ethical privacy considerations, and information about the researcher. A follow-up email was sent one week after the initial email was sent to encourage participation in the study. Based on the sampling frame of forty to fifty thousand, the appropriate sampling size was determined to be 381 . After the first 381 responses were received, the survey was closed to further response. Of these responses, 210 respondents (55\%) took the survey to completion.

The survey began with a Demographic Information Sheet (DIS) containing seven items to collect participants' information to extract predictor variables in this study. Those variables are 1) age, 2) sex, 3) location, 4) length of previous overseas experiences, 5) length of studying English as second language, 6) frequency of interaction with Americans, 7) length of time in the United States. Two items within DIS, require the respondents to identify themselves based on sex and location. The remaining five items prompt the respondents to provide continuous, numerical answers to collect data about their intercultural backgrounds and ages. Variables four through seven are the focus of this research.

\subsection{Length of Residence}

Is the duration for which each Saudi sojourner spends inside the United States. This variable is one of the four variables used to predict the intercultural background of the targeted population. In this study, participants were asked to indicate how long they had been in the United States using a numerical format. This variable was used as a continuous, independent variable without coding. Moreover, the interval-ratio was used as a level of measurement. 


\subsection{Length of Previous Overseas Experience}

Is the duration for which each Saudi sojourner spent outside Saudi Arabia during his or her lifetime. This variable is one the four variables used to predict the intercultural background of the targeted population. Participants were asked to say how long they had been outside Saudi Arabia using a numerical format. This variable was used as a continuous, independent variable without coding. The interval-ratio was used as a level of measurement. Data on the length of previous oversees experience was collected as the total number of years and months the respondent has been outside of Saudi Arabia, both as part of the current study abroad experience and prior trips abroad.

\subsection{Length of Time Studying English as Second Language}

The duration for which each Saudi sojourner spent learning English before studying at American universities. This variable is one of the four variables that were used to predict the intercultural background of the targeted population. Participants were asked by the researcher to indicate how long they spent studying English in Arabia using a numerical format. This variable was used as a continuous, independent variable without coding. Interval-ratio was used as a level of measurement. Data on the length of studying English was collected as the total number of years and months the respondent has studied English.

\subsection{Frequency Interaction}

The repeated communication of two or more individuals in the same society (Carpendale \& Miller, 2004). Participants were asked to tell how many hours they interacted with Americans per day. This variable was used as a continuous, independent variable without coding. Interval-ratio was used as a level of measurement. Data on the frequency of interaction was collected as the total hours per day spent with Americans.

Intrapersonal identity conflict is the internal struggle relating to different aspects of one's identity. Such conflicts often engender insurmountable tensions, depression, and anxiety, as they are capable of yielding fractured identities (Leong \& Ward, 2000). To measure the extent to which an individual is struggling with intrapersonal identity conflict, Leong and Ward (2000) developed the Ethno-cultural Identity Conflict Scale (EICS), a 20 -statement instrument that asks respondents to rate their level of agreement using a five-point Likert scale from strongly disagree to strongly agree. The EICS provides scaled statements to assess subjective feelings of cultural contrast relating to the respondent's experience with intrapersonal identity conflict. In Leong and Ward's (2000) study of Chinese sojourners in Singapore $(\mathrm{N}=106)$, fourteen of the twenty statements were tested and confirmed to be predictors of identity conflict with a strong reliability (Cronbach's Alpha score of 0.80 ).

\section{Results}

Of the 186 respondents that completed both the DIS and EICS questions, $63.44 \%$ ( $\mathrm{n}=118$ ) were males, 35.48\% $(\mathrm{n}=66)$ were female, and $1.08 \%(\mathrm{n}=2)$ did not specify their sex. Regarding location, $38.17 \%(\mathrm{n}=71)$ were attending schools in the South; $31.18 \%(\mathrm{n}=58)$ were attending schools in the Northeast; $15.05 \%(\mathrm{n}=28)$ were attending schools in the West; $14.52 \%(\mathrm{n}=27)$ were attending schools in the Midwest, and $1.08 \%(\mathrm{n}=2)$ did not specify their locations. Respondents were an average of 27 years old, with an age range from 19 to 55 years. The length of residency in the United States for the respondents per the EICS ranged from a few months to 27 years with a mean of 2.8 years and their length of studying English as a second language before coming to the United States ranged from 0 months to 10 years with a mean of 1.21 years. Additionally, the results show that the EICS respondents' overseas intercultural experiences ranged from 1 month to 43 years with a mean of 5 years, and their interactions with Americans varied from less than an hour to more than 12 hours per day with a mean of 4 hours per day. DIS variable frequencies and percentages are provided in Table 1. 
Table 1. The characteristics of the participants as frequency and percentage

\begin{tabular}{|c|c|c|c|}
\hline Characteristic & & Frequency & Percentage \\
\hline \multirow[t]{3}{*}{ Sex } & Male & 135 & $64.30 \%$ \\
\hline & Female & 73 & $34.80 \%$ \\
\hline & N/A & 2 & $1.00 \%$ \\
\hline \multirow[t]{4}{*}{ Age } & $18-27$ & 121 & $57.60 \%$ \\
\hline & $28-37$ & 81 & $38.60 \%$ \\
\hline & $38-47$ & 6 & $2.90 \%$ \\
\hline & $48-57$ & 2 & $1.00 \%$ \\
\hline \multirow[t]{5}{*}{ Location } & South & 80 & $38.10 \%$ \\
\hline & North-East & 67 & $31.90 \%$ \\
\hline & Mid-West & 31 & $14.80 \%$ \\
\hline & West & 29 & $13.80 \%$ \\
\hline & N/A & 3 & $1.40 \%$ \\
\hline \multirow[t]{6}{*}{ Interaction with Americans } & $<1$ hour per day & 59 & $28.10 \%$ \\
\hline & 1-4 hours per day & 76 & $36.20 \%$ \\
\hline & 5-8 hours per day & 49 & $23.30 \%$ \\
\hline & $9-12$ hours per day & 16 & $7.60 \%$ \\
\hline & $>12$ hours per day & 8 & $3.80 \%$ \\
\hline & N/A & 2 & $1.00 \%$ \\
\hline \multirow[t]{6}{*}{ Length of Residency in USA } & $<1$ year & 14 & $6.70 \%$ \\
\hline & $1-3$ years & 115 & $54.80 \%$ \\
\hline & $4-6$ years & 64 & $30.50 \%$ \\
\hline & $7-10$ years & 14 & $6.70 \%$ \\
\hline & $>10$ years & 1 & $0.50 \%$ \\
\hline & N/A & 2 & $1.00 \%$ \\
\hline \multirow[t]{6}{*}{ Overseas Experience } & $<1$ year & 26 & $12.40 \%$ \\
\hline & $1-3$ years & 87 & $41.40 \%$ \\
\hline & $4-6$ years & 60 & $28.60 \%$ \\
\hline & $7-9$ years & 11 & $5.20 \%$ \\
\hline & $>9$ years & 21 & $10.00 \%$ \\
\hline & N/A & 5 & $2.40 \%$ \\
\hline \multirow[t]{5}{*}{ Length of Studying English } & $<1$ year & 84 & $40 \%$ \\
\hline & $1-3$ years & 111 & $52.90 \%$ \\
\hline & $4-6$ years & 6 & $2.90 \%$ \\
\hline & $>6$ years & 6 & $2.90 \%$ \\
\hline & N/A & 3 & $1.40 \%$ \\
\hline
\end{tabular}

EICS scores suggest that respondents are experiencing low to moderate levels of intrapersonal identity conflict. The statement average was 2.37 and the instrument average was 47.4. EICS instrument scores ranged from 23 to 84 , with statement averages ranging from 1.15 to 4.20 , expressing a range from no identity conflict to high identity conflict. Table 2 reflects the frequencies, means, medians, modes, and standard deviations for each statement on the EICS. 
Table 2. EICS frequencies, means, median, mode, and standard deviations

\begin{tabular}{|c|c|c|c|c|c|c|}
\hline No. & Survey item & $\mathrm{n}$ & M & Median & Mode & SD \\
\hline 1 & $\begin{array}{l}\text { No matter what the circumstances are, I have a clear sense of who } \\
\text { I am }\end{array}$ & 210 & 1.78 & 2 & 1 & 0.95 \\
\hline 2 & $\begin{array}{l}\text { I have difficulties fitting into the wider society because of my } \\
\text { cultural background }\end{array}$ & 210 & 2.6 & 2 & 2 & 1.19 \\
\hline 3 & $\begin{array}{l}\text { In general, I do not think that people from my ethnic group know } \\
\text { the real me. }\end{array}$ & 209 & 3.02 & 3 & 3 & 1.09 \\
\hline 4 & I sometimes do not know where I belong & 209 & 2.24 & 2 & 1 & 1.26 \\
\hline 5 & $\begin{array}{l}\text { I am an outsider in both my own ethnic group and the wider } \\
\text { society }\end{array}$ & 209 & 2.63 & 3 & 3 & 1.17 \\
\hline 6 & $\begin{array}{l}\text { Because of my cultural heritage, I sometimes wonder who I really } \\
\text { am }\end{array}$ & 207 & 2.05 & 2 & 1 & 1.13 \\
\hline 7 & I experience conflict over my identity & 207 & 2.32 & 2 & 1 & 1.17 \\
\hline 8 & $\begin{array}{l}\text { I find it impossible to be part of both my cultural group and the } \\
\text { wider society }\end{array}$ & 209 & 2.39 & 2 & 2 & 1.17 \\
\hline 9 & I am uncertain about my values and beliefs & 209 & 1.99 & 2 & 1 & 1.15 \\
\hline 10 & I have serious concerns about my identity & 208 & 2.12 & 2 & 1 & 1.26 \\
\hline 11 & People tend to see me as I see myself & 206 & 2.86 & 3 & 3 & 0.98 \\
\hline 12 & I do not know which culture I belong to & 206 & 1.84 & 1 & 1 & 1.11 \\
\hline 13 & I find it hard to maintain my cultural values in everyday life & 206 & 2.76 & 3 & 2 & 1.2 \\
\hline 14 & I sometimes question my cultural identity & 205 & 2.59 & 2 & 2 & 1.21 \\
\hline 15 & $\begin{array}{l}\text { I am confused about the different demands placed on me by } \\
\text { family and other people }\end{array}$ & 205 & 2.57 & 2 & 2 & 1.27 \\
\hline 16 & Sometimes I do not know myself & 205 & 2.12 & 2 & 1 & 1.17 \\
\hline 17 & $\begin{array}{l}\text { I find it easy to maintain my traditional culture and to be part of } \\
\text { the larger society }\end{array}$ & 204 & 2.65 & 2 & 2 & 1.14 \\
\hline 18 & I feel confident moving between cultures & 205 & 2.37 & 2 & 2 & 1.11 \\
\hline 19 & I have difficulties fitting in with members of my ethnic group & 206 & 2.59 & 3 & 2 & 1.14 \\
\hline 20 & I am sometimes confused about who I really am & 205 & 2 & 2 & 1 & 1.2 \\
\hline
\end{tabular}

\subsection{Relationship between the Intercultural Background and Identity Conflict}

The research question asks the following: Is there a relationship between the exposure variables (the length of time spent in the United States, the length of previous experiences outside Saudi Arabia, the length of time studying English as second language, and the frequency and nature of interactions with Americans) and interpersonal identity conflict? In order to answer this question, four Pearson's product-moment correlation tests were run individually to assess the relationship between the four intercultural background variables and the EICS scores (see Table 3). It was found that these relationships were not statistically significant, given that $r=-0.021$ and $\mathrm{p}>0.05$ for the length of previous experiences outside Saudi Arabia, $r=-0.094$ and $p>0.05$ for the time spent in the United States, $r=-0.076$ and $\mathrm{p}>0.05$ for the frequency interaction with Americans, and $\mathrm{r}=-0.034$ and $\mathrm{p}>0.05$ for the length of studying English as second language prior to arriving in the States. Table 3 summarizes the results of the Pearson correlation test of students' intercultural background with the EICS scores. 
Table 3. Relationship between intercultural background variables and EICS scores

\begin{tabular}{lllll}
\hline & $\begin{array}{l}\text { Length of time } \\
\text { spent in the United } \\
\text { States }\end{array}$ & $\begin{array}{l}\text { Length of previous } \\
\text { experiences outside } \\
\text { Saudi Arabia }\end{array}$ & $\begin{array}{l}\text { Length of time studying } \\
\text { English as second language } \\
\text { prior to going to the U.S. }\end{array}$ & $\begin{array}{l}\text { Frequency of } \\
\text { interaction with the } \\
\text { American people }\end{array}$ \\
\hline Pearson correlation & -0.094 & -0.021 & -0.034 & -0.076 \\
Significance (2-tailed) & 0.265 & 0.779 & 0.684 & 0.304 \\
\hline
\end{tabular}

\section{Discussion and Conclusion}

The data presented within this research does not present a statistically significant relationship between any of the four variables of exposure and EICS scores based on Pearson product-moment correlation tests. However, the exposure variables demonstrate the degree of exposure to American culture. A majority of respondents spend less than four hours a day interacting with Americans (64.30\%), have resided in the United States less than three years $(61.50 \%)$, have spent less than years overseas $(53.80 \%)$, and have studied English less than three years $(92.90 \%)$. Despite this relatively limited exposure, especially in terms of language, the average level of intrapersonal identity conflict was 47.4 points, with an average per statement of 2.37 . This EICS score suggests that Saudi students have low to moderate levels of intrapersonal identity conflict. More specifically, $8 \%$ of respondent strongly disagree that they exhibit identity conflict, $48.5 \%$ of respondents disagree that they exhibit identity conflict, $36.6 \%$ of respondents neither agree not disagree, $6.9 \%$ of respondents agree that they are facing identity conflict, and no respondent strongly agreed that they exhibit identity conflict. Therefore, despite these relatively low levels of exposure, the majority of respondents do not feel that they are experiencing intrapersonal identity conflict. As so, this research fails to conclude that there is a relationship between intercultural exposure and intrapersonal identity conflict.

It is important to consider that acculturation is not merely the output of exposure. Exposure is one of many factors that impact acculturation and acculturation is one of many factors that impact identity conflict. Berry (2005) discusses acculturation strategies, including the constraints imposed by the host culture. Strategies, the author argues, rely on two fundamental questions: What is the value of maintain cultural heritage? What is the value of developing relationships with larger society of the host culture? If value is seen in developing in both areas, the individual will integrate. If value is not seen in either area, the individual will marginalize. If value is only seen in maintaining cultural heritage, the individual will separate. Finally, if value is only seen in developing relationships with the host culture, the individual will assimilate (Berry, 2005). Further research is needed to assess the relationship, if any, between patterns of integration, marginalization, separation, and assimilation amongst Saudi Arabian students studying in the United States.

It is important to note that although this research has not concluded a relationship between intercultural exposure and identity conflict that this lack of relationship is a finding in itself. Assessing this relationship was an important step towards developing a more robust understanding of the factors impacting acculturation and identity conflict. As Furnham and Bochnet (1982) provide that sojourner's experiences, individual differences, and cultural differences are all factors that determine how one will respond to a foreign culture, this research has only touched on one of many factors that are to be considered in future research of Saudi sojourners. More specifically, this research has correlated exposure to identity shock to test Guirdham's (1999) statement that an individual's ability to survive culture shock is affected by "knowledge of the culture and its language, stereotypes of and attitudes towards people in the other culture, being able to suspend evaluation of other people's behavior and understanding the self as a cultural being" (p. 272). Although Ward (1996) and Guirdham (1999) have asserted that cross-cultural adaptation for sojourners is affected by factors of exposure, this research has failed to find a relationship. As this research included the factors listed by Ward (1996) to be factors of exposure, there is one variable that this research did not include: cultural orientation programs. Therefore, the next step of this research is to incorporate experiences with cultural orientation programs.

This research focuses on Saudi sojourners which have all come through the King Abdullah Scholarship Program (KASP). As potential conflicts of acculturation are perceived to be able to be alleviated by cultural acclimation programs, such as orientations for Saudi students in the United States, future research must consider both the nature of orientation and preparation, if any, provided by KASP and how this potentially differentiates the Saudi sojourner population from other sojourner students in the United States. With this in consideration, further research is also needed to assess differences between Saudi sojourners and sojourners of other nationalities and cultures. 


\section{References}

Berry, J. W. (2006). Acculturation: A conceptual overview. In M. H. Bornstein, \& L. R. Cote (Eds.), Acculturation and parent-child relationships: Measurement (pp. 13-30). Mahwah, NJ: Lawrence Erlbaum.

Brewer, M. B. (1999). The psychology of prejudice: Ingroup love or outgroup hate? Journal of Social Issues, 55(3), 429-444. https://doi.org/10.1111/0022-4537.00126

Carpendale, J. I., \& Miiller, U. (2004). Social Interaction and the Development of Rationality and Morality: An Introduction. In Social Interaction and the Development of Knowledge (pp. 1-18). Mahwah, NJ: Lawrence Erlbaum Associates.

Erikson, E. H. (1950). Childhood and Society. New York: Norton.

Furnham, A., \& Bochner, S. (1982). Social difficulty in a foreign culture: An empirical analysis of culture shock. In S. Bochner (Ed.), Cultures in Contact: Studies in Cross-Cultural Interaction (pp. 161-198). Oxford: Pergamon Press. https://doi.org/10.1016/B978-0-08-025805-8.50016-0

Greene, S. (1999). Understanding party identification: A social identity approach. Political Psychology, 20(2), 393-403. https://doi.org/10.1111/0162-895X.00150

Guirdham, M. (1999). Communicating across cultures. London: Purdue University Press. https://doi.org/10.1007/978-1-349-27462-8

Haas, M. L. (2012). The Clash of Ideologies: Middle Eastern Politics and American Security. New York, NY: Oxford University Press. https://doi.org/10.1093/acprof:oso/9780199838424.001.0001

Habernas, J. (2003). The future of human nature. Malden, MA : Polity.

Herrmann, E. (2007). Humans have evolved specialized skills of social cognition: The cultural intelligence hypothesis. Science, 317, 1360. https://doi.org/10.1126/science.1146282

Huntington, S. P. (1996). The clash of civilizations and the remaking of world order. New York: Simon and Schuster.

Lankshear, C., \& Knobel, M. (2004). A Handbook for Teacher Research. Columbus, OH: Open University Press.

Law, F. M., \& Guo, G. J. (2010). Orientation course and cultural adjustment cycle: An orientation course for first-year Chinese international college students and its impact on their ways of coping with stress, anger expression, and psychological well-being. New Waves-Educational Research \& Development, 13(1), 43-61.

Leong, C.-H., \& Ward, C. (2000). Identity conflict in sojourners. International Journal of Intercultural Relations, 24, 763-776. https://doi.org/10.1016/S0147-1767(00)00030-4

Lin, G., \& Yi, J. K. (1997). Asian international students' adjustment' issues and program suggestions. College Student Journal, 31(4), 473-480.

Livengood, J., \& Stodolska, M. (2003). Leisure behavior and travel patterns of Muslim-Americans in response to the events of September 11. Paper presented at the 99th Association of American Geographers Conference, New Orleans, LA.

Maati, M. (2011). Cultural attaché in the United States is the beacon of Saudi Arabia science and culture in America and the new building reflects this vision. Al-Mubtaath, 194, 14-19.

O'Guinn, T. C., \& Faber, R. J. (1985). New perspectives on acculturation: The relationship of general and role specific acculturation with Hispanics' consumer attitudes. Advances in Consumer Research, 12(1), 113-117.

Persons, S. (1987). Ethnic studies at Chicago: 1904-45. Urbana, IL: University of Illinois Press.

Rubin, M., \& Hewstone, M. (2004). Social identity, system justification, and social dominance: Commentary on Reicher, Jost et al., and Sidanius et al. Political Psychology, 25(6), 823-844. https://doi.org/10.1111/j.1467-9221.2004.00400.x

Said, E. (1977). Orientalism. London: Penguin.

Salhi, K. (2006). Slimane Benaïssa from Exile in the theatre to theatre in exile: Ambiguous traumas and conflicts in the Algerian diasporic drama. The Journal of North African Studies, 11(4), 373-407. https://doi.org/10.1080/13629380601036429

Slocum-Bradley, N. R. (2008). Promoting conflict or peace through identity. Burlington, VT: Ashgate. 
Smith, E. J. (1991). Ethnic identity development: Toward the development of a theory within the context of majority/minority status. Journal of Counseling \& Development, 70(1), 181-188. https://doi.org/10.1002/j.1556-6676.1991.tb01581.x

Tajfel, H., \& Turner, J. C. (1996). The social identity theory of intergroup behaviour. In S. Worchel, \& W. G. Austin (Eds.), Psychology of intergroup relations (pp. 7-24). Chicago, IL: Nelson-Hall.

Ward, C. (1996). Acculturation. In D. Landis, \& R. S. Bhagat (Eds.), Handbook of Intercultural Training. Thousand Oaks.

Ward, C., \& Kennedy, A. (1999). The measurement of sociocultural adaptation. International Journal of Intercultural Relations, 23(4), 659-677. https://doi.org/10.1016/S0147-1767(99)00014-0

Ward, C., Stuart, J., \& Kus, L. (2011). The Construction and Validation of a Measure of Ethno-Cultural Identity $\begin{array}{lllll}\text { Conflict. Journal of Personality } & \text { 4ssessment, }\end{array}$ https://doi.org/10.1080/00223891.2011.558872

Worchel, S., \& Mitchell, T. R. (1972). An Evaluation of the Effectiveness of the Culture Assimilator in Thailand and Greece. Journal of Applied Psychology, 56(6), 472-479. https://doi.org/10.1037/h0033759

\section{Copyrights}

Copyright for this article is retained by the author(s), with first publication rights granted to the journal.

This is an open-access article distributed under the terms and conditions of the Creative Commons Attribution license (http://creativecommons.org/licenses/by/4.0/). 